\title{
THE SEC SAFE HARBOR FOR FORECASTS-A STEP IN THE RIGHT DIRECTION?
}

A financial forecast projects revenues, profits, earnings per share, or other features of the economic future of a company. Forecasts may be presented im prepared announcements or simply through confirmation to securities analysts that their own projections are "im the ball park."1 These forecasts, along with other "soft information,"2 are highly relevant to investment decisions because they assess the future pros-

THE FOLLOWING CITATIONS WILL BE USED IN THIS COMMENT:

Sec. Act Release No. 6084, [1979 Transfer Binder] FED. SEC. L. REP. (CCH) I] 82, 117 [hereinafter cited as Sec. Act Release No. 6084];

Sec. Act Release No. 5993, [1978 Transfer Binder] Fed. SEC. L. ReP. (CCH) I 81,757 [hereinafter cited as Sec. Act Release No. 5993];

Sec. Act Release No. 5699 [1975-76 Transfer Binder] FED. SEC. L. REP. (CCH) If 80,461 [hereinafter cited as Sec. Act Release No. 5699];

House Comm. on INTerstate and Foreign Commerce, 95Th Cong., Ist Sess., Report of the Advisory COMm. on Corporate Disclosure to the Securities and Exchange COMMISSION (Comm. Print 1977) [hereinafter cited as REPORT];

J. Cox, FinANCIAL INFORMation, Accounting AND the LAW (1980) [hereinafter cited as J. Cox];

Fiflis, Soft Information: The SEC's Former Exogenous Zone, 26 U.C.L.A. L. REv. 95 (1978) [hereinafter cited as Fiflis];

Mann, Prospectuses: Unreadable or Just Unread?-A Proposal to Reexamine Policies Against Permitting Projections, 40 Geo. WASH. L. REv. 222 (197I) [hereinafter cited as Mann];

Schneider, Nits, Grits, and Soft Information in SEC Filings, 121 U. PA. L. REv. 254 (1972) [hereinafter cited as Schneider].

1. J. Cox 268.

2. "Soft information" is defined as "opinions, predictions, analyses and other subjective evaluations," as distinguished from "hard information," which is defined as "statements concerning objectively veriflable historical facts." REPORT 347.

One commentator described soft information as follows:

Although a comprehensive definition of soft information is not readily apparent, several non-exclusive and non-exhaustive categories can be identified: (I) forward-looking statements concerning the future, such as projections, forecasts, predictions, and statements concernimg plans and expectations; (2) statements concerning past or present situations when the maker of the statement lacks the data necessary to prove its accuracyfor example, information on a company's historical share of the market, when it does not have access to precise statistics concerning its competitors; (3) infornation based primarily on subjective evaluations-for example, representations concerning the competence or integrity of management, the relative efficiency of a manufacturing operation, or the appraised value of assets; (4) statements of motive, purpose, or intention, since it is frequently easier to verify objectively what was done than to determine why it was donefor exampIe, explanation of the reasons for which an auditor has been discharged; (5) statements involving qualifying words, such as "excellent," "ingenious," "efficient" and "imaginative," for which there are no generally accepted objective standards of ineasurement in most contexts.

Schneider 255. Schneider further noted the difficulty involved in classifying certam information: "'Hard' and 'sof' inust be recognized as highly relative concepts suggesting no sharp dividing line. Many apparently hard statements have soft cores and vice versa." Id. 256. 


\section{pects of a company.}

The Securities and Exchange Commission has traditionally prohibited disclosure of most soft mformation in documents filed with the Commission, although the information was often dissemmated through imformal means such as press releases and other publications. ${ }^{3}$ Since 1972, however, the Commission has exhibited a willmgness to allow, and even to encourage, the disclosure of financial forecasts and certain other soft information. ${ }^{4}$ A recent example of this change in attitude is the adoption of Securities Act Regulation section $230.175^{5}$ (rule 175), which provides a "safe harbor" for voluntary disclosure of a "forwardlooking statement." 6

3. It has been the Commission's long-standing policy not to permit projections and predictions in prospectuses and reports filed with the Commission. Such documents are designed to elicit material facts. Their factual character is widely recognized. Investors and their advisors are at liberty to make their own projections based on the disclosures resulting from the Commission's requirements. A real danger exists, in the Study's judgment, that projections appearing in prospectuses and other documents filed under the securities laws and reviewed by the Commission would be accorded a greater measure of validity by the unsophisticated than they would deserve.

Securities and Exchange Commission, Disclosure to Investors-A Reappraisal or Federal Administrative Policies UNDER the '33 AND '34 ACts 96 (1969) (the "Wheat Report"), summarized in [Special Studies 1963-1972 Transfer Binder] FED. SEC. L. REP. (CCH) \ 74,601; see Gerstle v. Gamble-Skogmo, Inc., 478 F.2d 1281, 1294 (2d Cir. 1973); Fiflis 97. See generally Sowards, The Wheat Report and Reform of Federal Securities Regulation, 23 VAND. L. REV. 495 (1970) (general discussion of the Wheat Report).

4. In 1972 the SEC held public hearings to study estimates, foreeasts, and projections. Sec. Exch. Act Release No. 9844, [1972-73 Transfer Binder] FED. SEC. L. ReP. (CCH) I 79, 075. The next year it issued a policy statement declaring its intention to pronulgate rules for disclosure of projections. Sec. Act Release No. 5362, [1972-73 Transfer Binder] FED. SEC. L. REP. (CCH) ף 79,211. See text accoinpanying notes 53-55 infra. The SEC next proposed a complieated and detailed set of rules in 1975. Sec. Act Release No. 5581, [1974-75 Transfer Binder] FEd. SEC. L. REP. (CCH) If 80,167. Due to heavy criticism, the Commission withdrew the proposed rules one year later. Sec. Act. Release No. 5699. See notes 68-76 infra and accoinpanying text. In 1976 the Advisory Committee on Corporate Disclosure, a study committee appointed by the SEC, began an examination of the corporate disclosure systen. It subinitted a two-volume report at the conclusion of its investigation in 1978. REPORT. The SEC issued a generally favorable response to the Advisory Committee's recommendations and authorized the Division of Corporation Finance to draft recommendations. Sec. Act Release No. 5906, [1978 Transfer Binder] FED. SEC. L. REP. (CCH) If 81,505. Later in 1978 the SEC adopted "guides" for diselosing projections of future economic performance, Sec. Act Release No. 5992, [1978 Transfer Binder] FED. SEc. L. Rep. (CCH) I 81,756, and proposed a safe harbor rule for projections, Sec. Act ReleaseNo. 5993. See notes 136-39 infra and accompanying text. The SEC adopted a safe harbor rule on June 25, 1979. Sec. Act Release No. 6084. See note 83 infra.

5. 44 Fed. Reg. 38,810 (1979); Sec. Act Reg. \& 230.175, [1979] 1 Fed. Sec. L. Rep. (CCH) 3715. Part of the text of rule 175 is quoted in note 83 infra.

6. For the purpose of rule 175, the tern "forward-looking statement" is defined as follows:

(1) a statement contaiming a projection of revenues, incoine (loss), earnings (loss) per

share, capital expenditures, dividends, capital structure or other financial iteins;

(2) a stateinent of management's plans and objectives for future operations;

(3) a statement of future economic perfornance contained in management's discussion and analysis of the summary of earnings (as called for by Guides 22 and 1 under the 
The purpose of the rule is to encourage disclosure of projections, both in Commission filings and elsewhere, by protecting issuers and inanageinent ${ }^{7}$ from liability for misleading investors if projections are inade in good faith and have a reasonable basis. ${ }^{8}$ This Comment will examme the purposes of the safe harbor provision and the developinent of the current rule. It will then analyze the provisions of rule 175 , emphasizing alternative approaches that would clarify the rule and encourage disclosure by increasing management's protection froin liability.

\section{The Development of the SEC's Policy Favoring Forecast DisClOSURE}

\section{A. Arguments Against Disclosure of Forecasts.}

For many years, the Securities and Exchange Commission's policies largely excluded soft information from Commission documents. ${ }^{9}$ Issuers, underwriters, and their attorneys generally acquiesced in this exclusionary policy as a matter of self-protection. ${ }^{10}$ Although the Commission lias been retreating gradually from this position, it is important to review the reasons for the exclusionary policy because many of the same concerns continue to influence the development of the Commission's policies regarding forecast disclosure. ${ }^{11}$

Securities Act of 1933 and the Securities Exchange Act of 1934 and by instruction 5 to the Quarterly Report on Form 10-Q); or

(4) disclosed statements of the assumptions underlying or relating to any of the statements described in (1), (2), or (3) above.

44 Fed. Reg. 38,810 (1979). In the interest of brevity, future references to forward-looking information of the type covered by the safe harbor will be referred to as projections or forecasts.

7. The rule covers projections made "by or on behalf of an issuer or by an outside reviewer retained by the issuer." 44 Fed. Reg. 38,812 (1979).

8. Sec. Act Release No. 6084 , at 81,938 .

9. See note 3 supra. The SEC formerly permitted disclosure of specified soft information only. For example, the Commission tolerated disclosure of soft information filed in relation to acquisitions, tender offers, and proxy contests-situations in which an investor needs fair as opposed to conservative disclosure. In addition, disclosure of certain negative soft information was sometimes mandatory. For example, the SEC has required disclosure on such subjects as plant efficiency, management integrity, labor relations, anticipated changes in a company's competitive position, and trends refiected in recent intermi earnings when that information was negative. Moreover, Form S-11 for real estate offerings and the application of proceeds section of prospectuses require the disclosure of certain forward-looking information. Schneider 260-62.

10. Schneider 259. Managements are not anxious to expose thenselves needlessly to potential liability by making soft representations that may be difficult to substantiate and may prove to be incorrect. Id.

11. The Commission, however, lias not retreated from its prohibition of "specific future market values," although the broad interpretation of this phrase, described in Gerstle v. Gamble \& Skogmo, Inc., 478 F.2d 1281, 1294 (2d Cir. 1973), has been radically diminished. See Sec. Act. Release No. 5695, [1975-76 Transfer Binder] FED. SEC. L. REP. (CCH) ף 72,212. 
1. The Risk of Misleading Unsophisticated Investors Through Disclosure. The primary purpose of the statutory disclosure system of the Securities Act ${ }^{12}$ and the Exchange Act $^{13}$ is to provide investors with a sound basis for making rational and informed investment decisions. ${ }^{14}$ Historically, the Securities and Exchange Commission has impleinented this goal through disclosure policies designed to imform and protect unsophisticated investors. ${ }^{15}$ As a result, Commission practices have often deprived the investment community of useful information because of fears that the information inight be misundcrstood or given undue reliance by less knowledgeable investors. ${ }^{16}$ For example, before the passage of rule 175, the Commission confined disclosure in Commission filings to historical or objectively verifiable imformation that had a higl degree of reliability. This policy lcd investors to assume, justifiably, that all information in Commission documents had been prepared with considerable care, and was thus accurate. Therefore, according to the Commission's origmal view, if soft imformation appeared in a filing, investors would assume that it too had a high degrce of reliability, that objective evidence supported the forecasts, or that the predictions would almost certainly be fulfilled. ${ }^{17}$

Many courts have expressed similar concerns about the misleading nature of projections. ${ }^{18}$ An often-cited example is Union Pacific Railroad v. Chicago \& Northwestern Railway, ${ }^{19}$ a case involving a proxy contest between two railroads in an attempt to take over a third company. In a report to shareliolders, the defendant coinpany predicted savings of seventy-five million dollars from an anticipated thrce-way inerger. On the authority of a Securities and Exchange Commission

12. Securities Act of 1933,15 U.S.C. $\$ \S 77$ a-77aa (1976).

13. Exchange Act of 1934, 15 U.S.C. $\S \S 78 \mathrm{a}-780,78 \mathrm{p}-78 \mathrm{hh}$ (1976).

14. REPORT 347.

15. Id. 348. In cases of perceived conflict between the disclosure objective of providing meaningful information to the investment community and the objective of protccting unsophisticated investors from their own ignorance, the former frequently has been subordinated to the latter. Id.

16. Id.

17. Schneider 258. "[A]ccording to the traditional SEC view, the inclusion of soft information in filings would clothe such information with an unduly high aura of credibility." Id. The bootstrapping in this argument is readily apparent. If the public assumes that the information is objectively verifiable, it does so because filings have been confined to hard information in the past. If disclosure of soft information is allowed, these assumptions about SEC fllings should disappear. Id. 258-59.

18. See, e.g., Counstock-Dexter Mines, Inc., 10 S.E.C. 358,372 (1941) (estimates of mineral resources stated as an entry on the balance sheet); Thomas Bond, Inc., 5 S.E.C. 60, 71 (1939) (use of definite figures in estimates of future profits by a company that had not commenced operations held misleading). But of. American Kid Co., 1 S.E.C. 694 (1936) (projections with a reasonable basis may be included in filings unless they give an appearance of unwarranted reliability).

19. 226 F. Supp. 400,409 (N.D. Ill. 1964). 
rule that citcd predictions of earnings as its first example of what may be false or misleading, the court held that the projection of earnings was misleading per se. ${ }^{20}$ Judge Hoffman echoed the Securities and Exchange Commission's traditional view on earnings projections:

Bald statements contrary to concrete and historic fact run the risk of ready refutation and exposure, and to that degree are self-policing. Predictions, estimates, and opinions are more elusive and may present graver dangers of misleading the investing public. They lend themselves to this evil by allowing facts to be suggested or iniplied without direct statement. Even if they do not tend to induce belief in any particular fact, they nonetheless iniport the existence of unspecified facts which support the conclusion. The shareholder nay be led readily to assume, contrary to fact, that the predictor has special knowledge or umique information to bear out fully his prediction, and be induced to rely upon a supposed expert judgment of the inysteries of finance .... Whether the prediction is the product of an imtent to mislead or of innocent overenthusiasm, the misleading effect upon the investing public is the same. ${ }^{21}$

Conversely, it has been suggested that the assumption that investors will be misled underestimates the capability of investors, who are generally accustomed to dealing with soft information through the nor-

20. Id. at 408. At that time, rule 14a-9 offered "predictions as to specific future market values, earnings, or dividends" as an example of what may be misleading or false. Since then, howevcr, the SEC has amended the rule to remove predictions of future earnings and dividends from the examples of what is misleading per se im a proxy statement. See Sec. Act Release No. 6084; Sec. Act Release No. 5699.

21. 226 F. Supp. at 408-09. The court also quoted with approval from an article by Harry Heller, a former member of the SEC Division of Corporation Finance. In the article, which is perhaps the best defonse of the SEC's practice, Heller explaimed the Commission's prohibition on earnings projects as follows:

Since an expert can speak with authority only as to subjects upon which he has professional knowledge and since no eugineering course or other professional training has ever been known to qualify anyone as a clairvoyant, atteinpts by companies to predict future earnings on their own or on the authority of experts have almost invariably been held by the Commission to be misleading because they suggest to the investor a competence and authority which in fact does not exist.

Heller, Disclosure Requirements Under Federal Securities Regulation, 16 Bus. LAw. 300, 307 (1961).

Another widely quoted commentator attacked the SEC's traditional position and criticized the Union Pacific court for holding that the "projection was misleading just because it was a projection, entirely apart from the question whether in fact it might have been sound." Kripke, The SEC, the Accountants, Some Myths and Some Realities, 45 N.Y.U.L. REv. 1151, 1198 (1970).

The courts and the SEC have since abandoned the traditional position. For example, in Nicewarner v. Bleavins, 244 F. Supp. 261 (D. Col. 1965), defendant's predictions of profits and success of an invention did not violate the securities laws, because the court determined that there were circumstances that made the predictions believable and it did not appear that the defendant would have known of their falsity by taking reasonable precautions. See also Milberg v. Western Pac. R.R., 51 F.R.D. 280 (S.D.N.Y. 1970), appeal dismissed, 443 F.2d 1301 (2d Cir. 1971). 
mal workings of the market. ${ }^{22}$ Investors certainly are aware of the inherent uncertainties of projection information, especially when forewarned by cautionary language. ${ }^{23}$ In addition, even if a few investors fail to appreciate the rehability of forecasts, the benefits of making more relevant information available to all investors outweigh the detriment of a disclosure system geared to the lowest common denommator of investor sophistication. ${ }^{24}$

\section{Availability of Forecast Information to Investors Despite} Prohibitions on Disclosure. The Securities and Exchange Commission has argued that even though the investor does not receive important soft information in filings, the information is available to him through other sources. The unsophisticated investor, for example, may receive information froun investment advisors. In this filtration process, sophisticated investment intermediaries collect information about the issuer, evaluate the offering, and dissemmate their projections directly to investors as well as to a wide audience of securities dealers and salesmen, who in turn use the projections in making recommendations to potential investors. ${ }^{25}$ Of.course, analysts must have access to managcment's forecasts in order for the filtration process to operate. Many companics are willing to disclose forecasts to analysts because the companies believe that attention from well-informed analysts has a positive effect on stock values. ${ }^{26}$ Also, managenient may liope to quiet the public deinand for protection of individual investors to some degree by niaking complex financial data available to analysts, who in turn make investment decisions for many individuals.

Proponents of forecast disclosure argue, however, that it is unfair to inform analysts of this valuable information while denying access to individuals who may wish to use this sanue information to make their

22. Schneider 269. See also Merrifield, Projections in SEC Filings: Debate Rages Over Worth, in II SEC '74 at 149, 162-63 (1974), quoted in REPORT A-312.

23. REPORT A-312. But see Mann 231 (despite boldface legend on each prospectus stating that the SEC has not approved the securities or passed on the adequacy or accuracy of the prospectus, investors believe that the SEC has determined that the information is reliable).

24. REPORT A-312; Schneider 268. For widely traded securities, the understanding of sophisticates is beheved to be impounded in the market price so that the unsophisticated can hardly be hurt. See text accompanying note 116 infra.

25. Mann 226-27. A former member of the SEC's Division of Corporation Finance stated that the filtration process was one of the reasons Congress imposed a waiting period in the registration process: "The act thus operates to put the security dealer, who should possess the financial and econouric erudition necessary to analyze and evaluate the material required by law to be included in the registration statements and prospectuses, between the imvestor and the coinpany and its investment bankers." Heller, supra note 21, at 301-02 n.6.

26. See note 88 infra and accoinpanying text. 
own investinent decisions. ${ }^{27}$ Moreover, if investors inust rely on the filtration process to receive necessary information, the Securities and Exchange Commission's disclosure program has not fulfilled its statutory purpose. Disclosure documents should furnish all inforniation necessary for both the professional intermediaries and the individual investors to arrive at their investinent decisions through independent analysis. ${ }^{28}$

3. Fear That Disclosure of Forecasts Will Create Substantial Legal Liabilities. Perhaps the inost difficult problein accoinpanying any increased publication of forecasts is the possibility of civil liability for a projection that proves incorrect or omits inaterial facts. ${ }^{29}$ To traditionahsts, the possibility of liability condemns a pro-disclosure policy for several reasons. First, in soine instances, corporations would disclose and later be found liable for unintentional misrepresentations. Second, and inore likely, corporations would foresee the risk of liability and either make no disclosures or inake very conservative disclosures of little value to investors. ${ }^{30}$ Furthermore, disclosure of forecasts in Coinmission filings might brimg undue pressure on inanagement to perform consistently with its predictions, contrary to the exercise of sound business judginent. ${ }^{31}$

Fear of liability is a legitimate concern that should be considered

27. Reiling \& Burton, Financial Statements: Signposts As Well As Milestones, Harv. Bus. REv., Nov.-Dec. 1972, at 45, 46-47. Proponents of disclosure also argue that investors should not be required to pay analysts for important soft information simply because management disseminates company information in a discriminatory fashion. REPORT A-313.

28. Mann 227. See also Sowards, supra note 3, at 498-502.

29. At common law, projections were classified as opinions rather than facts. Therefore, good faith projections that proved incorrect would not support an action for fraud or deceit. See Crosby v. Emerson, 142 F. 713 (3d Cir. 1906); Robinson v. Parks, 76 Md. 118, 24 A. 411 (1892); Dean, Public Dissemination of Projected Earnings-Pros and Cons, 25 MERCER L. REv. 511, 531 (1974); Wise, Fearless Forecasts: Corporate Liability for Earnings Forecasts That Miss the Mark, 17 CoRP. PraC. COM. 501, 508 (1976). In contrast, numerous provisions of the securities laws have been interpreted to create potential liability for inaccurate or incomplete forecasts. For example, hability can be based on sections 11 and 12 of the 1933 Act, 15 U.S.C. $\$ 77 \mathrm{k}-1$ (1976), and section 10b and rule 10b-5 of the 1934 Act, 15 U.S.C. $\$ 78 j(b)$ (1976).

The Wheat Report, a 1969 study of the SEC's disclosure policy, noted a corporate concern that "problems of civil liability would be insurmountable unless projections in prospectuses were expressly granted immunity" from suit. Wheat Report, supra note 3, at 95 . The Report concluded that the SEC's traditional pohcy should be contimued despite the acknowledged value of forecasts to investors. FED. SEC. L. REP., supra note 3, at 65,242. For a inore coinplete discussion of the liability doctrines, see notes $95-180$ infra and accompanying text.

30. See REPORT A-313.

31. Id. A-314. One writer, who supports the SEC's exclusionary policy, concluded:

Even though nuanagement nuay be in a better position than anyone else to prepare then, projections should be left to analysts and securities dealers and not forced on management whose primary concern is and nuust continue to be the profitable operation of the business. Manageinent should not be required to expose itself or the company's assets or 
in any policy decisions concerning disclosure of forecasts. The potential for hability exists, of course, whether or not the Commission allows the disclosure of forecasts in Commission documents. For example, courts have found that hability could be based upon misleading forecasts disseminated through speeches and press releases. ${ }^{32}$ Nevertheless, the potential for liability is a major deterrent to increased disclosure of forecasts. ${ }^{33}$

\section{B. The Securities and Exchange Commission's Rejection of the Ban Against Forecast Disclosure.}

Because of the Securities and Exchange Commission's efforts to protect unsophisticated investors and its reliance upon the filtration systein to distribute soft information, few investors received sufficient disclosure of projections. ${ }^{34}$ Disclosure in Commission filings was extremely conservative, with emphasis on negative, adverse, or pessimistic factors, and contained more elaboration of the risks involved im investments than of the prospects for earnings. ${ }^{35}$ One well-known commentator concluded that "the prospectus ha[d] become a routine, meaningless document which [did] not serve its purpose." 36 The Com-

existing stockholers to unnecessary risks, suits, and liabilities undisclosed in the balance sheet.

Dean, supra note 29, at 534.

32. See, e.g., Marx v. Computer Sciences Corp., 507 F.2d 485 (9th Cir. 1974); SEC v. Texas Gulf Sulphur Co., 401 F.2d 833 (2d Cir. 1968) (en banc), cert. denied, 404 U.S. 1005 (1971).

33. Other traditional arguments against forecasts in SEC filing imclude the following: (1) preparation costs will be excessive, Note, Disclosure of Future-Oriented Information Under the Securities Laws, 88 YALE L.J. 338, 356 (1978); (2) disclosure of forecasts will weaken the firm's competitive position, id. 357 ; (3) disclosure of forecasts will precipitate undue investor interest in short term coinpany performance, REPORT A-312; (4) management will lave the opportunity to use forecasts as a device to manipulate security prices, id. A-314; and (5) prospectuses are designed to disclose material facts, not conjecture and speculation as to the future, Mann 231.

34. Comment, The SEC Policy for Projections: New Problems in Disclosture, 21 U.C.L.A. L. REv. 242, 245 (1973). Moreover, reliance on the filtration process may have resulted in unequal access to information as well as emphasis on who received the information first. Id. 245-46.

35. Schneider 264. In fact, SEC policies fostered this pessinism by requiring disclosure of foreseeable risks that could adversely affect future operations, while excludimg disclosure of similar predictions when they were favorable. Mann 225. See also Blue Chip Stamps v. Manor Drug Stores, 421 U.S. 723 (1975).

36. Address by Homer Kripke, Annual Meeting of Banking, Corporation, and Business Law Section, New York State Bar Association (Jan. 27, 1972), quoted in Schneider 265. In Feit v. Leasco Data Processing Equip. Corp., 332 F. Supp. 544 (E.D.N.Y. 1971), the court stated in reference to prospectuses:

In at least some imstances, what has developed in lieu of the open disclosure envisioned by the Congress is a literary art form calculated to communicate as little of the essential information as possible while exuding an air of total candor. Masters of this medium utilize turgid prose to enshroud the occasional critical revelation im a morass of dull, and-to all but the sophisticates-useless financial and historical data. In the face of such obfuscatory tactics the commou or even the moderately well imformed investor is 
mission responded by authorizing a public ruleinaking proceeding to reconsider whether, and under what circuinstances, it should permit or require the disclosure of forecasts. ${ }^{37}$

In announcing the 1972 hearings, the Securities and Exchange Commission chairman stated that "despite serious problems of rehability and hability," forecasts do circulate and do affect stock values, whether or not required or permitted in Commission filings. ${ }^{38}$ Cominentators have gone even further to suggest that carefully prepared forecasts are crucial to investment decisions because they are among the most significant factors influencing securities prices. ${ }^{39}$ In other words, "[w] here the issuer is going, not where he has been, will determine future inarket prices and the ultimate success of the investinent decision." $" 40$ This assertion is supported by evidence indicating that meinbers of the financial cominunity determine the value of securities by capitalizing projected future imcoine. ${ }^{41}$ Similarly, an advocate of disclosure maintained:

If there is any hope that the public or even the professionals can make an informed investment judgment, it must start froin a crystallization of all of the plethora of information into a projection for the future. The management is in the best position to make the initial estimate; on the basis of it the professional or investor could then make his own nodifications. No other single change could add as much meaning to the uninanageable and unfocused flood of facts in present Cominission documents. ${ }^{42}$

almost as much at the mercy of the issuer as was his pre-SEC parent. He cannot by reading the prospectus discern the merit of the offering.

Id. at 565. Bruce Mann has argued: "The real problem with the statutory prospectus is not that it is unreadable but that it is unread. It is unread because it does not contain that information which the investor considers crucial to his investment decision." Mann 223.

37. Sec. Act Release No. 9844, supra note 4. Specifically, the Commission called for considerations of

whether projections should continue to be prohibited in filings with the Commission or should be permitted or required; whether guidelimes should be established for projections; whether standard assumptions for projections are feasible; whether a particular format for the presentation of projects, or the independent verification of projections, should be required; and to wliat extent there may be liabilities for projections under the securities laws.

Dean, supra note 29 , at 521.

38. Sec. Act Release No. 9844, supra note 4, at 82,323; Gormley, Financial Forecasts: Problems and Considerations, 6 SEc. REg. L.J. 32, 41 (1978). The 1972 hearings lasted 14 days, during which 53 persons testified and over 200 otlers sent written opinions. Their comments are summarized in [1972] 180 SEC. Reg. \& L. Rep. (BNA) A-5 to 6; [1972] 179 SEc. REg. \& L. Rep. (BNA) A-7 to 10; [1972] 178 SEC. REg. \& L. ReP. (BNA) A-6 to 19.

39. See Report A-315; Herwitz, Projections and Forecasts, 4 ANN. InST. Sec. Reg. 323, 325

(1973); Mann 224; Sclmeider 280.

40. Mann 224.

41. See Kripke, supra note 21, at 1197.

42. Id. 1199. 
Since inanagement is in a unique position to analyze the firm's future prospects, proponents of disclosure argue that companies should have the the responsibility, or at least the opportunity, to make forecasts in Commission filings. ${ }^{43}$ Such disclosure would not impose significant additional costs, at least for companies that already compile the information for their own internal use. ${ }^{44}$ Investors could use the projections to evaluate the quality of management and to check on inforination provided by professional analysts. ${ }^{45}$

Studies indicate, however, that forecasts by management and analysts are not particularly accurate, and that they become even less exact as they predict further into the future. ${ }^{46}$ The question, then, is whether

43. REPORT A-315; see Merrifield, supra note 22, at 163.

44. Gray, Proposals for Systematic Disclosure of Corporate Forecasts, FinanCial ANALYSTs J., Jan.-Feb. 1973, at 64, 71; see [1972] 178 SEC. REG. \& L. ReP. (BNA) A-8 (witness at hearings testified that forecasting is "already a way of life for most corporations"). Further, though some companies may find it necessary to enlarge their planning and budgeting staffs in order to publish forecasts, they arguably will benefit from internal use of the information. Gray, supra at 71 . But cf. Dean, supra note 29, at 522 (costs of publishing forecasts may outweigh any public benefit; internal forecasts are used but certainly not in the form necessary for publication to those outside the firm).

45. REPORT A-316 to 17. A commentator suggested:

It may be time for the securities acts to require the dissemmation of information bearing on the competence of management, information which will give the public imsight into whether inanagement is doing its job by running the company in a proficient and professional inanner. . . .

Disclosure of corporate planning processes, budgets and projections may be a step in this direction. The mere disclosure of results of operations is not sufficient to test the quality of management. It is not only important to know what has liappened; it is equally or inore important to know how it happened and whether it was supposed to happen. A test of management is whether it is realistic about the goals of the company and whether it can orchestrate the dynamic parts of the company to obtain these goals, whether inanagement is efficient at planning and control.

Merrifield, supra note 22, at 168.

46. See, e.g., Basi, Carey, \& Twark, A Comparison of the Accuracy of Corporate and Security Analysts' Forecasts of Earnings, 51 Accounting Rev. 244 (1976); Cragg \& Malkiel, The Consensus and Accuracy of Some Predictions of the Growth of Corporate Earnings, 23 J. FINANCE 67 (1968); Daily, The Feasibility of Reporting Forecasted Information, 46 Accounting Rev. 686 (1971); Gonedes, Dopuch, \& Penman, Disclosure Rules, Information-Production, and Capital Mar. ket Equilibrium: The Case of Forecast Disclosure Rules, 14 J. Accounting RESEARCH 89 (1976); Green \& Segall, The Predictive Power of First-Quarter Earnings Reports, 40 J. Bus. 44 (1967); Imhoff, The Representativeness of Management Earnings Forecasts, 53 Accounting Rev. 836 (1978); McDonald, An Empirical Examination of the Reliability of Published Predictions of Futture Earnings, 48 Accounting Rev. 502 (1973). But cf. Copeland \& Marioni, Executives' Forecasts of Earnings per Share versus Forecasts of Naïve Models, 45 J. Bus. 497 (1972) (management's forecasts are significantly better than those derived from naive models).

An interesting subsidiary issue is whether inanagement forecasts are more accurate than those of analysts. One study revealed that while management predicted earnings with "somewhat less error and variance of error than their analyst counterparts," the difference between the two were not "statistically significant." Imhoff, supra at 848. See also Ruland, The Accuracy of Forecasts by Management and by Financial Analysts, 53 Accounting Rev. 439 (1978). But of. Basi, Carey, \& Twark, supra at 252-53 (manageinent's inside information leads to better forecasts). Actually, both types of forecasts are useful to the investor. The analyst has comparative information and 
investors receive any benefit from increased publication of forecasts that are not reasonably accurate. ${ }^{47}$ Additional studies conclude, however, that regardless of their accuracy, forecasts convey information that is valuable to investors. ${ }^{48}$ First, even if specific figures are not exact, the forecast conveys management's assessment of the future direction of the firm-probably one of the best estimates available. ${ }^{49}$ Second, the act of voluntary disclosure itself usually means that management has good news, or at least that management's planning allows it to be confident in its predictions. ${ }^{50}$ Finally, forecast disclosure affects stock prices, so its relevance to the market makes it valuable to investors. $^{\text {si }}$

Similarly, the Securities and Exchange Commission concluded after public hearings that management's assessment of a firm's future performance conveys information of "significant importance to the investor" and is "relied upon in the mvestment process." 52 Having reached this conclusion, the Commission next turned to the issue of how the forecasts were being disseminated.

In a 1973 policy statement on projections, the Commission ex-

brings objectivity to his forecast; management has special knowledge of internal factors and a greater sensitivity to the particular firm. Gray, supra note 44, at 65 .

In any event, conclusions reached in studies on the accuracy of forecasts are of limited usefulness in pohcymaking, sincc all of those studies necessarily examine only firms that voluntarily engage in forecasting. Such companies, it appears, have unique characteristics that limit the inferences that inay be drawn froin their experience and applied to all firms in forinulating a disclosure policy. J. Cox 269. For exanuple, companies that voluntarily publicize forecasts generally have a high degree of confidence in their forecasts at the time they are made. Basi, Carey, \& Twark, supra at 253. Furthennore, evidence indicates that managenent is more willing to make forecasts when they expect earnings to increase than when they anticipate no growth or a decline in earnings. J. Cox 269.

47. J. Cox 269-71.

48. See Gonedes, Dopuch, \& Penman, supra note 46; Jaggi, A Note on the Information Content of Corporate Annual Earnings Forecasts, 53 Accounring Rev. 961 (1978); Patell, Corporate Forecasts of Earnings per Share and Stock Price Behavior: Empirical Tests, 14 J. Accounring RESEARCH 246 (1976). See generally J. Cox 267-93.

49. See REPORT A-315. 253.

50. See Patell, supra note 48. See also J. Cox 269; Basi, Carey, \& Twark, supra note 46, at

51. Patell, supra note 48. See J. Cox 278. Professor Kripke stated:

Although the research evidence on the accuracy of projections is not encouraging, this seems to me not to be the point. That investors pay attention to projections is conceded. The time has come to end the SEC's excessive preoccupation with verifiable data .... to assume that the investor . . . can exercise a common sense skepticisn toward nonverifiable information, and to relax the rigidity of the disclosure process.

Kripke, A Search for a Meaningful Securities Disclosure Policy, 31 Bus. LAw. 293, 314 (1975). It is interesting that the trend in the courts deterunining hability has been toward focusing on the relevance, or materiality, of forecasts as opposed to their accuracy. See text accompanying notes 10006 infra.

52. Sec. Act Release No. 5362, supra note 4 , at 82,667 . 
pressed concern that management forecasts had been conveyed to outsiders by informal practices that led to uneven and unfair dissemination of forecast mformation..$^{53}$ As a result, the Commission determined that a change im its exclusionary policies "would assist in protection of investors and would be in the public interest." 54 The Commission decided, therefore, to take the first steps toward integrating projections into the disclosure system by permitting, but not requiring, the publication of forecasts in Commission documents. The Commission also characterized issuance of forecasts to outsiders as a material event and thereby required full and immediate disclosure of such commumications. ${ }^{55}$ Rules detailing and implementing the Commission's new policy on projections were forthcoming.

\section{I1. Implementing an Effective Forecast Disclosure Policy}

\section{A. The Securities and Exchange Commission's Initial Proposals for Forecast Disclosure.}

The Commission's first attempts to draft workable rules implementing the forecast disclosure goal illustrate the formidable obstacles posed by this problem. Over two years after the decision to encourage forecast disclosure, the Commission proposed rules that permitted disclosure of forecast information, but required management to comply with complex provisions requirmg filings with the Commission and disclosure of particular information. ${ }^{56}$ In addition, in order to alleviate

\section{Id. 82,666 .}

54. Id. 82,667 .

55. Id. 82,665-66. It is important to note the Commission's characterization of this disclosure as "material" becanse failure to disclose material facts creates liabilities under the securities laws. See notes 95-111 infra and accompanying text.

56. Sec. Act Release No. 5581, supra note 4. See generally REPORT A-276 to 93. The proposed rules would have required a filing with the SEC of every projection disclosed to outsiders, with information on the circumstances of disclosure and the material assumptions underlying each projection. The rules defined a "projection" as

a statement made by an issner regarding material future revenues, sales, net income or earnings per share of the issuer, expressed as a specific amount, range of amounts . . . or percentage variation from a specific amount . . . , or a confirmation by an issuer of any such statement made by another person . . . . A . . . note indicates that statements that another person's projection is "in the ballpark," "attainable" or "on target" are examples of a confirmation.

Sec. Act Release No. 5581, supra note 4, at 85,302 . The proposal did not define the term "material," but stated:

Any such statement relating to the issuer's total future revenues, sales, net income or earnings per share wonld be material; a statement relating to the sales or revenues of a subsidiary or of a particular line of busmess might be material, depending on the facts .... Rules 405 and $12 \mathrm{~b}-2$ presently contain definitions of "material" which would be apphicable ....

Id. Companies were also required to publish forecasts previously mcluded in prospectuses and in annual reports to shareholders and the SEC, along with comparisons with actual results. Further, 
management fears of per se liability when forecasts were not realized the Commission proposed a safe harbor provision that defined the circumstances under whieh a forecast could be made without liability. ${ }^{57}$ The Commission, however, sought to restrict the safe harbor to situations in which there was a great likelihood of a reasonable forecast. ${ }^{58}$ Hence, the safe harbor was narrowly defined. ${ }^{59}$

These proposals met widespread criticism. ${ }^{60}$ The major concern expressed by issuers was that the rules, although designed to widen the availability of information, would actually cause companies to curtail their disclosure for fear of liability or because they were unwilling to start the cycle of required filings with the Commission. ${ }^{61}$ Moreover, if management did disclose, costs would be incurred in docuinenting the basic assumptions underlymg the forecast and in filing the inevitable revisions. ${ }^{62}$ Commentators were also critical of the vague language used in the safe harbor provision. Subjective standards such as "reasonable care," "carefully reviewed and approved," "rcasonable factual basis," and "good faith judgment" were viewed as invitations to litigation $^{63}$ and as mere illusions of a safe harbor agamst liability. ${ }^{64}$ Furthermore, the definition of "projection" was so vague that it was

they were required to disclose in SEC filings each revision of the forecast, or an explanation of inability to do so, along with any reviews by auditors, and any reports the reviews generated. Finally, they were required to file with the SEC their determination to cease inaking forecasts.

If forecasts were published in prospectuses, issuers would be subject to prospectus liabihity provisions, which are the most stringent annong the securities laws. J. Cox 268; see Securities Act of $1933, \S 11,15$ U.S.C. $\S 77 \mathrm{k}$ (1976). Finally, the rules permitted, but did not require, fihing and publishing predictions of revenues and net imcome, with disclosure of material assumptions. Sec. Act Release No. 5581, supra note 4; see Gormley, supra note 38, at 42.

57. Report A-286 to 87; see Sec. Act Release No. 5581, supra note 4, at 85,302.

58. The SEC did not provide any clear guidance, however, as to when a great likelihood of a reasonable forecast inight exist. Sec. Act Release No. 5581, supra note 4, at 85,303. See notes 15180 infra and aceompanying text (criticisin of SEC for lack of clear standards).

59. To clain safe harbor protection, issuers would have to meet certain requirements: sufficient experience (defined as at least three years) in reporting and budgeting; preparation of forecasts with reasonable care by qualified personnel; and approval by managements at appropriate levels. Disclosure requirements would have forced management to disclose, at a minimuin, revenues, net income, and earnings per share (each of which must be expressed exactly or within a reasonable range of figures). The proposal also would have required disclosure of material assumptions inade in the forecast and the circumstances of any review by another party. Finally, the projections would come within the safe harbor only if they represented management's good faith judginent and had a reasonable factual basis. Sec. Act. Release No. 5581, supra note 4, at $85,303-04$.

60. REPORT A-291 to 93; see [1975] 320 SEC. REG. \& L. REP. (BNA) D-1 to D-4.

61. SEC. REG. \& L. REP., supra note 60 , at D-1. In fact, many registrants indicated their intention to limit significantly the flow of information to the investenent community if the rules were adopted. REPORT A-293.

62. REPORT A-291 to 92.

63. Id. A-292.

64. See Gormley, supra note 38 , at 42 . 
criticized for being excessively broad ${ }^{65}$ and not inclusive enough. ${ }^{66}$ Thus, although the majority of those who commented to the Commission favored a change in its disclosure policies, few supported the Commission's proposal. ${ }^{67}$

In response to the "important legal, disclosure policy and technical issues raised by the commentators," the Securities and Exchange Commission withdrew its proposals in April 1976.68 The Commission then altered its pohicies. In the same announcement in which the proposals were withdrawn, the Commission proposed guides 62 and $4 .{ }^{69}$ The guides, which were subsequently adopted, ${ }^{70}$ indicate the practices that the Division of Corporation Finance will follow in administering the Commission's disclosure requirements. As proposed, they were neither rules of the Commission nor expressions of the Commission's official approval. ${ }^{71}$ The guides state that disclosure of projections in Commission docuinents will be allowed, subject to three requirements: (1) they inust be inade in good faith and have a reasonable basis; ${ }^{72}$ (2) they inust be presented in an appropriate format; ${ }^{73}$ and (3) they must facilitate imvestor understanding of the basis for and limitations of projections. ${ }^{74}$

65. Id.

66. See Kripke, supra note 51, at 315 . Another commentator suggested that (1) the prerequisite of three years as a reporting company may not be the proper standard for determining the ability of a company to make a reasonable forecast; (2) there should not be a minimum requirement for the content of forecasts, simce a company might be able accurately to predict revenues and net income, but not fully diluted earnings per share; (3) instead of confining forecasts to a narrow range of figures, inultiple estimates based upon alternate assumptions should be allowed; (4) the burden of proof concerning whether a forecast is protected by the safe harbor should not be clearly placed on either party. Merow, SEC Proposed Rules: Civil Liability and Problems of the Securities Firm, 7 ANN. INST. SEC. REG. 115-16 (1975).

67. Sec. Act Release No. 5699.

68. Id. 86,201-02. The Commission did, however, adopt a technical amendment that deleted the reference im rule 14a-9 to predictions of earnings as an example of what may be misleading in a proxy statement. $I d .86,201$.

69. Id. 86,202-03.

70. Sec. Act Release No. 5992, supra note 4. By the time the guides were adopted in revised form in 1978, another guide had been adopted as guide 4; thus proposed guide 4 became guide 5 when finally adopted.

71. Sec Act Release No. 5699, at 86,201. When finally adopted, however, the guides expressed the position of the Commission that the making of projections was to be encouraged. Sec. Act Release No. 5992, supra note 4, at 81,040 .

72. The guides cite history of operations, experience in forecasting, and outside review of projections as examples of what may provide a reasonable basis for forecasts. Guide 62, 1 FED. SEC. L. REP. (CCH) If 3822, at 3349 (1979).

73. In determining the appropriate format, the guides indicate that it may be necessary to forecast revenues, net income, and earnings per share in order to avoid any misleading inferences that may arise when single items reflect contradictory trends. Multiple projections based on varying assumptions (as opposed to a specific number or range) are allowed. $I d$.

74. The Division concluded that disclosure of the assumptions that management sees as most significant to the forecasts would enhance investor understanding, although the guides do not require publication of such assumptions. Id. 
The Securities and Exchange Commission's proposed action ${ }^{75}$ reflected a policy of tolerance that neither encouraged nor discouraged the disclosure of forecasts, and that made no perceptible advance toward resolution of the liability problem. ${ }^{76}$ The Commission took a significant step in 1976, however, by appointing an advisory committee to reexamine the entire corporate disclosure system. ${ }^{77}$ The committee's recommendations served as the principal impetus for the Commission's final adoption of a safe harbor rule.

\section{B. The Securities and Exchange Commission's Disclosure and Safe Harbor Policy: A Critical View of Rule 175.}

The Advisory Committee on Corporate Disclosure addressed two broad issues in its report ${ }^{78}$ to the Commission: first, whether there are public policy and economic justifications for the Commission's mandatory disclosure system, and second, whether the information presently required in Commission filings is useful to investors, or if other data that is now prohibited would be of greater use. ${ }^{79}$ In a thorough analysis of the Commission's disclosure policies, the committee concluded that the present mandatory disclosure system sliould be mamtamed, but that the Commission should encourage greater voluntary disclosure of soft information im its filings. ${ }^{80}$ Despite disagreement among the committee inembers on other aspects of the report, there was virtual unanimity on the recommendations regarding the disclosure of soft information. ${ }^{81}$ The committee endorsed the Commission's

75. Sec. Act Release No. 5699.

76. Gormley, supra note 38, at 43. After the projections proposals generated so much controversy, the SEC received little comment on their proposed guides. See Proposed Guides for Earnings Projections Get Relatively Tame Response, [1976] 361 SEC. REG. \& L. REP. (BNA) D-1 to D-2.

77. [1976] 349 SEC. Reg. \& L. REP. (BNA) A-18.

78. REPORT. See generally Sommer, Survey: Report of the Advisory Committee on Corporate Disclosure to the Securities and Exchange Commission-Foreword, 26 U.C.L.A. L. REv. 48 (1978).

79. Fiflis 104.

80. REPORT VI-XLIX, 344-79. A cost benefit analysis of the mandatory disclosure system is beyond the scope of this Comment. The debate still continues over the worth of the system, with the prevailing view taking the position that the benefits outweigh the costs. See, e.g., Benston, The Costs and Benefits of Government-Required Disclosure: SEC and FTC Requirements-An Appraisal, in Corporations AT THE Crossroads: GovernanCE AND ReForm 37, 67 (D. DeMott ed. 1980) ("costs to society of government-required disclosure exceed the benefits that may be derived therefrom"); Fiflis, Economic Analysis as One Phase of Utilitarianism, in CorPorations at The Crossroads: Governance and Reform 70 (D. DeMott ed. 1980) (utilitarian analysis, of which economic analysis is but one part, fails to support the conclusion that the costs of disclosure outweigh the benefits in a mandatory system). See also REPORT VI-XLIX; Kripke, Where Are We on Securities Disclosure After the Advisory Committee Report?, 6 SEC. REG. L.J. 99 (1978).

81. Fiflis 99. An explanation for the agreement could be that most of the recommendations on the disclosure of soft information call for voluntary disclosure, while much of the disagreement among the committee members focused on whether there should be a mandatory disclosure sys- 
departure from its traditional posture 'by recommending that the Commission actively encourage the disclosure of soft information. In addition, the committee proposed a safe harbor provision to facilitate such voluntary disclosure. ${ }^{82}$

In response to the committee report, the Commission adopted rule 175 , which creates a safe harbor for financial forecasts. ${ }^{83}$ The rule is designed to encourage disclosure of projections by protecting issuers from liability for projections that are voluntarily disclosed in Commis-

tem, as at present. Id. Chairman Sommer supported a mandatory disclosure system rather than the voluntary disclosure favored by the committee. See note 89 infra and accompanying text.

82. [1977-78 Transfer Binder] FED. SEC. L. REP. (CCH) I 81,357, at 88,663. One writer offered the following evaluation of the Report's recommendations:

Assuining that investors will engage in soine form of fundamental analysis, these recoininendations for increased disclosure will greatly increase the available relevant evidence of a firm's prospects, albeit with less than fully reliable data. Moreover, the experiment will test the hypothesis of those critics who suggest that market forces will cause managers to disclose ineaningful data. And, to the extent disclosures are in fact made, experience with them may reveal the need to take additional steps to further encourage, mandate, or prohibit disclosure. A period of experinentation will also allow more time for necessary research on portfolio analysis which, if its adherents' views are upheld, might obviate the need for firm-oriented disclosure.

The Report, whatever it lacks in other ways, cannot be faulted for proposing careful, yet progressive experimentation.

Fiflis 113-14.

83. Sec. Act Release No. 6084. The safe harbor rule as adopted, reads in part:

Liability for Forward-Looking Statements by Issuers Reg. If 230.175. (a) A statement within the coverage of paragraph (b) below which is made by or on behalf of an issuer or by an outside reviewer retamed by the issuer shall be deemed not to be a fraudulent statement (as defined in paragraph (d) below), unless it is shown that such statement was made or reaffirmed without a reasonable basis or was disclosed other than in good faith.

(b) This rule applies to (1) a forward looking statement (as defined in paragraph (c) below) made in a document filed with the Commission or im an annual report to shareholders meeting the requirements of Rules 14a-3(b) and (c) or 14c-3(a) and (b) under the Securities Exchange Act of 1934, (2) a statement reaffirming the forward looking statement referred to in (b)(1) subsequent to the date the document was filed or the annual report was made publicly available, or (3) a forward looking statement made prior to the date the document was filed or the date the annual report was made publicly available if such forward looking statement is reaffirmed in a filed document or annual report made publicly available withm a reasonable tine after the making of such forward looking stateinent.

(d) For the purpose of this rule the term "fraudulent statement" shall inean a statement which is an untrue statement of a material fact, a statement false or misleading with respect to any material fact, an omission to state a material fact necessary to make a statement not misleading, or which constitutes the einployment of a manipulative, deceptive, or fraudulent device, contrivance, scheine, transaction, act, practice, course of business, or an artifice to defraud, as those terms are used in the Securities Act of 1933 or the rules or regulations promulgated thereunder.

(e) Notwithstanding any of the provisions of paragraphs (a) through (d), this rule shall apply only to forward looking stateinents made by or on behalf of an issuer if, at the time such statements are inade or reaffirmed, the issuer is subject to the reporting requirements of the Securities Exchange Act of 1934 and has filed its most recent annual report on Form 10-K, or, if the issuer is not subject to the reporting requirements of the Securities Exchange Act of 1934, the statements are made in a registration statement filed under the Securities Act of 1933 .

(f) Notwithstanding any of the provisions of paragraphs (a) through (e), this rule does not apply to stateinents made by or on behalf of an issuer that is an investment company registered under the Investinent Company Act of 1940. 
sion filings or in annual reports to shareholders. ${ }^{84}$ Rule 175 is simpler and more direct than the Commission's origmal proposal and adopts in large part the recommendations of the Advisory Committee.

1. Voluntary Disclosure of Soft Information. The Advisory Committee recommended that disclosure be on a voluntary basis initially. The committee opposed a mandatory system because it felt that the Securities and Exchange Commission did not yet have the experience necessary to formulate specific rules for a mandatory system. Their report also concluded that it was unfair to require all companies to sustain the expenses and burdens associated with mandatory disclosure. Furthermore, "many companies would [have found] it difficult to prepare adequate projections due to lack of operating history, or industry conditions and should not be compelled to subject themselves to possible risks of liability for inaccurate projections." 85 The Commission adopted the committee's recommendation by permitting-but not requiring - the disclosure of soft information. ${ }^{86}$

A drawback of the voluntary disclosure system, however, is that issuers smiply may decide not to publicize their forecasts. 87 The report asserts that if the information is truly valuable, market forces, such as investor demand and the companies' interest in having analysts observe their progress, will compel production of the forecasts. ${ }^{88}$ This argument presents a troubling anomaly: the Advisory Committee and the Securities and Exchange Commission obviously believe that the information is important enough to investors to justify disclosure, and yet disclosure is not required. ${ }^{89}$ At the same time, the Commission requires disclosure of other information that is far less inportant to investment decisions. ${ }^{90}$ This inconsistency has led some commentators to suggest that a mandatory systen would better serve the Commission's

84. Sec. Act Release No. 6084.

85. Sec. Act Release No. 5992, supra note 4, at 81,037.

86. See Sec. Act Release No. 6084.

87. REPORT 354. In fact, the Advisory Committee's investigation revealed that few companies to date had voluntarily imcluded projcctions in their filings with the SEC even though registrants were cxpressly permitted to do so. Id. 353 n. 12 .

88. Id. 354-55. A Financial Analysts Federation study indicates that analysts may be discouraged from closely observing and reviewing a company if the coinpany has poor disclosure policies. Analysts' intcrest in a company may have a positive effect on its liquidity and stock market price. Thus, there is incentive for companies to disclose their forecasts voluntarily. In addition, when one firm in an industry discloses, others may be encouraged to disclose, and analysts can use the first disclosure as a lever to get information froin other companies. Id. 355 .

89. Sommer, supra note 78, at 55. Chairman Sommer concluded: "The Committee equivocated, and the Commission continues to equivocate, with respect to 'soft' information." Id.

90. For example, the SEC has required disclosure of compensation of top officers. Id. 
goal of equitable dissemination of important investment information. ${ }^{91}$ Although there was support for such a recommendation withm the Advisory Committee, the majority concluded that the Coinmission needed time to gam experience. ${ }^{92}$ The Coinmission, however, has already dealt with mandatory disclosure of soft information under other provisions of the securities laws. ${ }^{93}$ This experience should provide it with a sufficient basis for establishing a inandatory system. If the inforination is as important as the Commission, the courts, and the investors have concluded, ${ }^{94}$ disclosure should be required to allow all investors equal access to the information.

A final reason for adopting a inandatory disclosure policy is to avoid the contradictory policies created by the interaction of the voluntary disclosure rule and the principle that hability may be imposed for inisstateinents or omissions of inaterial facts. ${ }^{95}$ Despite early indications to the contrary, forecasts, in effect, are considered "facts" for securities law purposes. ${ }^{96}$ In addition, most forecasts will probably be characterized as "material." Under the Supreine Court decision in TSC Industries, Inc. v. Northway, Inc., ${ }^{97}$ which established the test of materiality for proxy rule violations, "a fact is inaterial if there is a substantial likelihood that a reasonable shareholder would consider it important in deciding how to vote."98 Courts have applied the test to

91. See Gray, supra note 44 , at 67 (fairness requires more systematic disclosure but forecasting should remain voluntary during initial trial period); Merrifield, supra note 22, at 154 (forwardlooking information should be made available to all imvestors because institutional investors presently have access to such essential investinent information); Reiling \& Burton, supra note 27, at 53 ("decision whether to make public forecasts should not be in the hands of management"); Schneider 270-73 (recommending selected mandatory disclosure supplemented by permissive disclosure).

92. Sec. Act Release No. 5992, supra note 4, at 81,037; see Sommer, supra notc 78, at 55.

93. See note 9 supra.

94. See note 51 supra, text accompanying notes 48-52 supra, \& notes $95-99$ infra.

95. Under the SEC's present policies, liability for a forecast could exist under the Securities Act of 1933 or the Securities Exchange Act of 1934. Particular provisions include sections 11 and 12 of the 1933 Act, which prohibit materially misleading statements in a registration statement or prospectus and section 10 and rule $10 \mathrm{~b}-5$ of the 1934 Act, which create liability for fraudulent or misleading statements. 15 U.S.C. $\$ \S 77 \mathrm{a}-77 \mathrm{aa}, 78 \mathrm{a}-78 \mathrm{jj}, 77 \mathrm{k}, 77 \mathrm{l}, 78 \mathrm{j}(\mathrm{b})$ (1976); Comment, The SEC Policy for Projeetions: New Problems in Disclosure, 21 U.C.L.A. L. REv. 242, 257 (1973).

96. See, e.g., G \& M, Inc. v. Newbern, 488 F.2d 742 (9th Cir. 1973). This is significant because forecast disclosure could occur in four types of filings, including registration stateinents under the Securities Act of 1933, proxy statements, tender offers, and periodic reports under the Securities Exchange Act of 1934. In all of these disclosures the terin "fact" is central in determining the existence of liability for misstatements or omissions of material "facts." Gillis, Disclosure of Corporate Projections, Financial ANAlysis J., Jan.-Feb. 1979 at 6, 72.

97. 426 U.S. 438 (1976).

98. Id. at 449 (emphasis added). Prior to TSC Industries, many courts applied the "might" test enunciated in Mills v. Electric Auto-Lite Co., 396 U.S. 375 (1970): whether a misstatement or an omission "Inight have been considered important by a reasonable shareholder who was in the 
determine materiality for other securities law purposes. ${ }^{99}$ Because there is a substantial likelihood in many cases that investors will consider forecast information valuable, courts frequently conclude that such information is material under the liability provisions.

Thus, although the Commission's rule informs companies that they may or may not disclose at their cloice, im reality a failure to disclose may create substantial liabilities. The liability problen arises on two levels. On the first level, compames choosing to engage im limited voluntary disclosure nuay discover their attempts to limit the amount of information disclosed thwarted by the obligation to disclose all material facts. For example, in Marx v. Computer Sciences Corp., ${ }^{100}$ the court lield that forecasts that fail to disclose material facts inay violate the securities laws. The case involved a projection by a computer company im a Securities and Excliange Commission filing that substantial research and development costs of a new computer system would be ainortized that year. A vice-president of the coinpany had also predicted in a speecli to security analysts that the company's revenues would exceed $\$ 105$ million, yielding profits of one dollar per share. The company failed to disclose, however, that the systein was not yet operational and that the company had not begun expensing the research and development costs. In fact, the project was abandoned shortly after the speech and the costs were written off. Profits were only one-third of what liad been predicted.

The Court of Appeals for the Nintlı Circuit concluded that failure to disclose in the forecast that the system was not being expensed and that there were other developinent problenis niay liave been a material omission under rule $10 \mathrm{~b}-5$. While it is not necessary to "detail every corporate event, current or prospective, whicli has or miglit liave some effect upon the accuracy of an earnings forecast," 101 the court stated, failure to disclose soine or all of thein niay have influenced the decision

process of deciding how to vote." Id. at 384. This difference may be of no consequence to a jury that is instructed as to materiality but it would assume significance when a complaint, as in TSC Industries, seeks summary judgment and the issue of materiality is dispositive. The standard may also serve to limit the quantity of disclosure. See 426 U.S. at $448-49$.

99. See, e.g., Santa Fe Indus., Inc. v. Green, 430 U.S. 462, 474 n.14 (1977) (test apphed in a $10 \mathrm{~b}-5$ action when no advance notice was given of a short-form merger). Sundstrand Corp. v. Sun Chemical Corp., 553 F.2d 1033 (7th Cir.), cert. denied, 434 U.S. 875 (1977) apphed the following test in a 10b-5 action: "whether "there is a substantial likelihood that a reasonable [investor] would consider [the omitted facts or misrepresentation] important in deciding' whether to invest." Id. at 1040 (quoting TSC Industries, Inc. v. Northway, Inc., 426 U.S. at 449).

100. 507 F.2d 485 (9th Cir. 1974).

101. Id. at 491-92. The court further stated that when an earnings projection is made, "such facts should be disclosed as are necessary to allay any misleadimg impression thereby created." Id. at 492. See Sundstrand Corp. v. Sun Cliemical Corp., 553 F.2d 1033 (7th Cir.), cert. denied, 434 
of a reasonable investor.

On the second level, now that corporations may no longer raise the Commission's nondisclosure policy as a defense, the failure to disclose forecast information may create liability for failure to disclose material facts. In Feit v. Leasco Data Processing Equipment Corp., ${ }^{102}$ which did not involve a forecast per se, but ratler another type of inforination, the court emphasized that estimates based on less than accurate data could be made as long as they were appropriately qualified, and that in certain circumstances disclosure was required. Feit involved Leasco's takeover of Reliance Insurance Company. A primary motivation for the takeover was Reliance's substantial "surplus surplus,"103 which amount Leasco did not disclose in its registration statement. Judge Wemstein held that this omission violated section 11 because the estimated amount of the surplus was a significant reason for the takeover and thus was inaterial information to investors. ${ }^{104}$ The court was not persuaded by Leasco's argument that it did not disclose the amount of the reserve because it had no information with which to verify its own estimates. ${ }^{105}$ The court furtler stated that Leasco had no reason to believe that its estimates were so inaccurate that they could not have been disclosed witl a carefully drafted qualifying statement about their reliability. ${ }^{106}$ It is important to notice the court's einphasis upon the materiality of the disclosure as opposed to the softness of the information. The clear implication of the Feit holding is that it is the materiality of soft information, including forecasts, and not its reliability, that com-

U.S. 875 (1977) (investors may be misled by failure to disclose fact that earnings estimates might be significantly overstated due to accounting gimmickry).

102. 332 F. Supp. 544 (E.D.N.Y. 1971).

103. "Surplus surplus" was defined in Feit as "the highly liquid assets of an insurance company which can be utilized in non-regulated enterprises." Id. at 551 .

104. The significance of [Leasco's] imtense interest in surplus surplus is that by failure to disclose the size of the fund Leasco hoped to acquire, it effectively denied the Reliance shareholders knowledge of one of the principal factors underlying the transaction. This insufficiency prevented accurate evaluation of the degree of interest of Leasco. Knowledge of the intensity of demaud is essential to determination of a fair price in a market economy.

Id. at 572 .

105. Leasco inaintained that it could not make an accurate estimate of the surplus surplus primarily because the lostility of Reliance's management foreclosed access to the information. Id. at 552.

106. Id. at 579. The court approved the following statement as an appropriate qualification:

[Due to reorganization plans there will be available to Leasco] approximately $\$ 125,000,000$ of excess surplus of Reliance. It is the opinion of Leasco that this amount represents funds which Reliance has on hand in excess of the legal requirements of its business. No assurances can be given that sucl excess funds will ultimately be made available to the Company in such amount or that if so made available that such funds will be profitably utilized by the Company.

Id. at 560 (empliasis by the court). 
pels its disclosure under the securities laws.

Another illustration is Gerstle v. Gamble-Skogmo, Inc., 107 in which the complaint alleged that a proxy statement was misleading because it did not disclose the current value of certain assets or the company's intention to sell those assets for a large profit immediately after the nerger. The defendants raised the Securities and Exchange Commission's exclusionary policy as a defense for not disclosing the estimated value of the assets. The Court of Appeals for the Second Circuit accepted the defense, but found liability on another basis. ${ }^{108}$ As a result of the Commission's decision to allow disclosure of projections and estimates, however, the exclusionary policy is no longer available as a defense. ${ }^{109}$ In effect, the Commission's voluntary disclosure policy puts corporations in a dilemma. On one hand, rule 175 instructs corporations to use their discretion in disclosing information. On the other hand, if a court finds the information would have been important to investors and yet was not voluntarily disclosed, the court could impose liability for the omission of inaterial facts. Replacing a clear prohibition with the contradictory and deceptive voluntarmess rule imposes a new and substantial burden on management. A mandatory disclosure system would alleviate these difficulties by specifymg the information to be disclosed. ${ }^{110}$ If an effective, clear safe harbor were joined with the disclosure requirement, ${ }^{111}$ management could disclose specific information with the assurance that additional disclosure would not be required to avoid hability for omission of material facts.

2. Limitations on the Type of Information Protected. The Coinmittee recommended disclosure of a broad range of forward-looking and analytical information. ${ }^{112}$ Under existing Commission guides,

107. 478 F.2d 1281 (2d Cir. 1973).

108. Judge Friendly stated:

The SEC may well determine that its policy [against disclosure of asset appraisals in proxy statements], while protecting investors who are considering the purchase of a security from the overoptimistic claims of management, may have deprived those who must decide whether or not to sell their securities, as the plaintiffs effectively did here, of valuable information, as Professor Kripke has argued . . . . But we would be loath to impose a huge liability on [Gamble] on the basis of what we regard as as substantial modification, if not reversal of the SEC's position on disclosure of appraisals in proxy statements, by way of its amicus brief in this case.

Id. at 1294 .

109. Fiflis 129-30, 145.

110. See text accoinpanying notes $177-80$ infra.

111. If the rationale for a safe harbor rule is to encourage disclosure, the safe harbor arguably has no function when disclosure is mandatory. In fact, however, a safe harbor could encourage management to go beyond boilerplate compliance with mandatory requirenents and disclose a broader range of information.

112. FED. SEC. L. REP., supra note 82, at 88,667. 
management already is required to disclose an analysis of certain financial data. ${ }^{13}$ The Advisory Committee endorsed this mandatory disclosure, but suggested that the guides be amended to require more qualitative than quantitative analysis. ${ }^{114}$ In addition, the committee recommended voluntary disclosure of planned capital expenditures and financing, management plans and objectives, dividend policies, and capital structure policies. ${ }^{115}$ In a significant departure froin traditional Securities and Exchange Commission policy, the Advisory Committee also recommended that the information disclosed be conducive to fully informed investment decisionmaking-that is, that the information be anned at sophisticated and knowledgeable investors. ${ }^{16}$ The knowledgeable investors would then be expected to disseminate the information to the general investors, and inarket prices would adjust efficiently to the information as interpreted by the sophisticated investors. ${ }^{117}$ An inportant inplication of the report's recommendation is that the disclosure of soft information should be permitted because sophisticated investors have the ability to weigh the soft information's relevance agamst its reliability. ${ }^{118}$

In accord with the Advisory Committee's recommendation, the Commission's safe harbor covers all projections of financial items, including financial forecasts, statements of manageinent plans and objectives, and future economic performance. ${ }^{119}$ Furthermore, and of particular innportance to the accounting profession, the Commission rule not only covers statements made by management but also stateinents made by outside reviewers on behalf of management. ${ }^{120}$ The

113. A verification and explanation of finaneial information is currently required of management in most 1933 and 1934 Act registration statements, annual reports, and other filings. See Guide No. 1 for Preparation and Filing of Registration Statements under the Securities Exchange Act of 1934, Sec. Exch. Act Release No. 10,961, [1979] 2 FED. SEC. L. REP. (CCH) II 23,060; Guide No. 22 for Preparation and Filing of Registration Statements, Sec. Act Release No. 4936, [1975] 1 FED. SEC. L. ReP. (CCH) If 3782.

114. Management analyses are often "nothing but banalties" because their boilerplate character provides little useful information to the imvestor. Fiflis 111 . The Committee believed that the discussions, which are currently presented in numerical percentages and figures, would be more meaningful if they were described in quahtative terms. It recommended, therefore, that the guides be modified to delete the numerical tests and to give broader latitude to registrants in deciding how to explaim their analyses. FED. SEC. L. REP., supra note 82, at 88,666-67.

115. FED. SEC. L. REP., supra note 82 , at 88,668 .

116. The report stated that "[t]he Commission should emphasize disclosure of information useful to reasonably knowledgeable investors willing to make the effort needed to study the disclosures, leaving to disseminators the development of simplified formats and summaries usable by less experienced and less knowledgeable investors." REPORT D-9.

117. Fiflis 106.

118. Id. 107.

119. Sec. Act Release No. 6084 , at 81,941 .

120. Id. 81,942 . 
safe harbor's protection is limited, however, to projections made in Commission filings and annual reports to shareholders. The safe harbor proposal in the report, on the other hand, also would have protected projections disseminated by such informal means as speeches to the financial commumity, press releases, and newsletters. ${ }^{121}$

Although rule 175 is a good initial attempt at encouraging the disclosure of information, the safe harbor as presently drafted does not fully achieve its purpose. Although the Commission recognizes the value of soft information to investors, it affords a safe harbor only for disclosure of forward-looking statements. The rule does not protect other useful information, such as evaluations of the integrity and quality of management, ${ }^{122}$ and predictions of general market trends. Furthermore, the rule protects only forecasts disclosed in Commission documents and amiual reports to shareholders. Coinpanies probably would be more willing to distribute forecast information to broad groups of investors if the rule protected disclosures in press releases, speeches, and other informal nueans of communication. Since investors benefit from disclosure of forecasts that are reasonably based and made in good faith, there is no reason to restrict the safe harbor to forecasts made in Commission documents, especially when one considers the more timely nature of informal disclosure.

3. Management's Obligation to Clarify Forecasts. The primcipal value of a projection disclosure policy hes in enhancing investor knowledge. The odds of achieving that goal may be reduced substantially unless precautions are taken to insure that investors are given a reasonably complete and accurate understanding of the basis for the projection. Nevertheless, the rules recommended by the committee do not demand disclosure of the material assumptions underlying a forecast. ${ }^{123}$ Scant justification was offered for not requiring disclosure of assumptions, other than that permissive disclosure would maximize the attractiveness of forecasting and provide time for gaining experience. ${ }^{124}$

Commentators, on the other hand, have insisted that disclosure of assumptions is essential to investor understanding. ${ }^{125}$ The assuinptions provide investors with a frainework for analyzing the projection ${ }^{126}$ and

121. Id. 81,938 . The Advisory Committee's version seems more effectively to encourage wide disseinination of forecasts to the investing public.

122. See REPORT A-353; Schneider 288-97.

123. REPORT 358.

124. Id.

125. Kell, The SEC's New Disclosure Rule on Forecasts, 25 MicH. Bus. Rev. 18, 19 (1973), quoted in REPORT 358 n.20.

126. REPORT 358. 
enable them to assign an appropriate degree of credibility to the forecast. ${ }^{127}$ In its comments to rule 175, the Securities and Exchange Commission recognized the significance of assumptions to investor understanding of forecasts. Nevertheless, rule 175 follows the committee's approach and inerely encourages disclosure of assumptions. ${ }^{128}$

Rule 175's approach to disclosure of nuaterial assumptions is not entirely satisfactory for several reasons. First, management may choose not to provide investors with this information, relymg on the absence of any clear directive to disclose. Second, this rehance on the rule's silence may be misplaced, as management may in fact be subject to hability for its failure to disclose. As the Commission warned, under certain circumstances disclosure of assumptions may be material to an understanding of the projected results. In such cases, disclosure of assumptions is mandatory under other provisions of the securities laws. ${ }^{129}$ Moreover, disclosure of key assumptions underlying a forecast may be necessary in order to meet the reasonable basis and good faith standards of the safe harbor rule. 130 An additional hidden possibility for hability arises because courts and the Securities and Exchange Commission impose a duty to correct forecasts that have become misleading. Under existing requirements of the securities laws, management is responsible for making full and prompt disclosure of material facts, both positive and negative, when it knows its earlier statements no longer have a reasonable basis. ${ }^{131}$ The Commission, in its release describing rule 175, explicitly imposes the same duty to correct on managements that disclose projections. Depending on the circumstances, a duty to correct arises if the projections have become inaccurate by virtue of subsequent events, or are later discovered to have been misleading or false from the outset and management has reason to know that persons are continumg to rely on the information. ${ }^{132}$

The court in Green v. Jonhop ${ }^{133}$ extended this affirmative duty by

127. Schneider 277. See also notes $22-24$ supra and accompanying text.

128. Sec. Act Release No. 6084 at 81,942 .

129. Id. See notes 100-06 supro \& 154-58 infra and accompanying text.

130. Sec. Act Release No. 6084, at 81,942. See notes $159-80$ infra and accompanying text.

131. See Sec. Act Release No. 5992, supra note 4.

132. Sec. Act Release No. 6084, at 81,943; see, e.g., SEC v. Shattuck Denn Mining Corp., 297 F. Supp. 470 (S.D.N.Y. 1968) (corporation president's failure to correct a press release that had become false and misleading). See also Fischer v. Kletz, 266 F. Supp. 180 (S.D.N.Y. 1967) (accountant's failure to disclose later finding of falsity in financial statcments that were included in annual reports to shareholders and filings with SEC). Whether the projections have becoine materially misleading will depend on factors such as the length of time between the making of the forecast and the occurrence of the subsequent event and the magnitude of the deviation. Sec. Act Release No. 6084, at 81,943-44.

133. 358 F. Supp. 413 (D. Or. 1973). 
requiring a company to correct a misleading earnings projection made by an outside source associated with the company. In this case, an underwriter projected that earnings would triple. The court concluded that there was no reasonable basis for the prediction, and held the company liable under rule $10 \mathrm{~b}-5$ for failure to correct the underwriter's misleading statement when management knew the projection was in circulation. ${ }^{134}$

Rule 175's silence on disclosure of assumptions and the duty to correct is a disservice both to investors and manageinent. This approach provides no assurance that this valuable information will be produced for the investor, and it arguably misleads management concerning its obhgations and potential liabilities. ${ }^{135}$ The interests of both groups would be advanced if these requirements were clearly defined.

4. The Safe Harbor for Projections. Unlike the Securities and Exchange Commission in its 1976 release, ${ }^{136}$ the Advisory Committee concluded that a safe harbor is necessary if firms are to be expected to disclose forecasts voluntarily. The Commission had determined that a safe harbor was not needed because projections made in good faith with a reasonable basis would not subject issuers to liability. ${ }^{137}$ Since the case law defining good faith and reasonable basis is unsettled, however, there is reason to believe that a safe harbor is necessary to relieve some of the fear of liability held by those who would disclose soft information. ${ }^{138}$ The committee's report, therefore, proposed a broad safe harbor to protect soft information disclosed both through informal communications and in Commission documents. ${ }^{139}$ The burden would be on the plaimtiff to prove that the forecast lacked a reasonable basis

134. The court stated that a company is "obligated to take some action when it learns of such misstatements or omissions and is aware that their publication or nonpublication will be misleading to members of the investing public." $I d$. at 420 .

135. See notes 100-06 supra \& 154-59 infra and accompanying text.

136. Sec. Act Release No. 5699.

137. Id.

138. REPORT 363, A-378. See notes 149-80 infra and accompanying text.

139. The report proposed the following safe larbor, which is virtually identical to the SEC's safe harbor for replacement cost information:

A statement of a management projection of future company economic performance or a statement of management plans and objectives for future company operations shall be deemed not to be an untrue statement of material fact; a stateinent false or misleadimg with respect to any material fact; an omission to state a material fact necessary to make a statement not misleading; or the employınent of a manipulative, deceptive, or fraudulent device, contrivance, scheme, transaction, act, practice, course of busmess, or an artifice to defraud, as those terms are used in the Securities Act of 1933, the Securities Exchange Act of 1934, or the Public Utility Holding Company Act of 1935, or rules and regulations thereunder, unless such information:

(1) Was prepared without a reasonable basis; or

(2) Was disclosed other than in good faith. 
or was not made in good faith. ${ }^{140}$

Although the Commission's general response to the Advisory Committee's recommendations was favorable, ${ }^{141}$ there were specific points of disagreement. The Commission, therefore, proposed two versions of a safe harbor rule for public comment. Version $A$, the more conservative proposal, would have protected only "statements made by or on behalf of the issuer . . ."142 The protection would be limited to forecasts of financial items such as revenue, mcome, and earnings per share. To qualify for protection from liability, the defendant would have to prove that the projection was prepared with a reasonable basis and disclosed in good faith. ${ }^{143}$ Version $B$ proposed adoption of the

REPORT 364. The Committee believed that its safe harbor was consistent with the present state of the law as reflected in recent court opinions. Id. 364.

140. RePort 364; see [1977-78 Transfer Binder] Fed. SEC. L. Rep. (CCH) ๆ 81,357, at 88,672. Other recommendations of the Advisory Committee concerning projections were:

a. . . comparisons of projections with actual results, including management analysis of any significant variance, should be encouraged but not required;

b. The iterns of information to be forecasted should rest within the discretion of management, but should be those most relevant in evaluating the coinpany's securities and should not be items whose projection would create inaterially misleading inferences;

c. Third party review of management projections should be permitted but not required;

d. Projections previously issued by management having currency at the time a registration statement is filed should be required to be included in the registration statement in their origimal form, or where necessary, in inodified form;

e. The time period to be covered by the projection should rest within the discretion of inanagement; and

f. Inclusion of projections in one Commission filing should not "lock" the registrant into including projections in future filings; likewise, registrants should be permitted to resume the inclusion of projections im filings after a prior discontinuance. However, companies should be encouraged not to discontinue or resume projections in filings without good cause.

REPORT 345-46.

141. See Preliminary Response of the Commission to the Recommendations of the Advisory Committee on Corporate Disclosure, Sec. Act Release No. 5906, supra note 4.

142. Sec. Act release No. 5993, at 81,043 . This provision, which would protect statements of an outside reviewer of managenent's forecasts, differs substantially from the Advisory Committee's recommendation, which applied to management's statements and did not specifically protect statements by third party reviewers or define "management." Id.

143. The Commission specifically invited comment on the effect that placement of the burden would have on the SEC's goal of encouraging the disclosure of forecasts. Id. 81,044. The SEC offered the following explanation for placing the burden on the defendant:

The Commission is proposing the rule in this manner since it is concerned that the burden imposed on a plaintiff-including the Conmission - could be insurmountable. It would be extrennely difficult to prove the absence of a reasonable basis or good faith, especially as to plaintiffs who would not have the Commission's investigatory procedures available and cannot engage in discovery prior to the filing of a complaint alleging a violation.

Moreover, Version A reflects the recognition that an issuer likely would be in a better position to prove that a projection was prepared with a reasonable basis and disclosed in good faith by virtue of its access to all the facts and circumstances surrounding the disclosure of a particular projection for which protection under the rule would be sought.

Id. (citation ornitted). 
report's recommendations. ${ }^{144}$ The safe harbor provision that the Commission finally adopted is a hybrid of these two versions.

a. Burden of proof. Under rule 175 the plaintiff has the burden of establishing both that a projection lacks reasonable basis and that it was not disclosed in good faith. ${ }^{145}$ The deterrent effect of placing the burden on the defendant was viewed as contrary to the Commission's goal of encouraging forecasts. In addition, commentators feared that the number of frivolous suits would increase, resulting in a considerable time and cost burden for management. ${ }^{146}$

In the past, some of the statutory liability provisions placed the burden of proof on the defendant, because the Commission believed that the burden would be insurmountable for plaintiffs with no inside knowledge of a company's activities. ${ }^{147}$ The case law demonstrates, however, that liberal discovery procedures, the availability of public information, and the Commission's broad investigatory powers provide plaintiffs with the tools necessary to prove their cases agamst defendants. ${ }^{148}$ The safe harbor rules inay also work to the advantage of plamtiffs. Although the safe harbor was designed to be an affirmative defense for issuer defendants who inet its two-pronged standard, it is likely that plaintiffs will use the Commission's standards to establish a

144. Id. 81,041-42; Gillis, supra note 96, at 77. Both versions of the rule protect disclosures in SEC documents and by informal ineans. Version $A$ limits protection to disclosures made by SEC registrants and reporting firms, and does not protect forecasts inade by registered investment companies. Version $B$ is not so limited. Sec. Act Release No. 5993. On the same day that the SEC proposed the two versions of the safe harbor, it adopted guide 62 under the Securities Act and guide 5 under the Securities Exchange Act. Sec. Act Release No. 5992, supra note 4. See notes 6976 supra and accompanying text.

145. Sec. Act Release No. 6084 , at 81,940 .

146. $I d$.

147. See id. In drafting liability sections 11 and 12 of the Securities Act of 1933, Congress expressed this same concern:

Every lawyer knows that with the facts in the control of the defendant it is practically impossible for a buyer to prove a state of knowledge or a failure to exercise due care on the part of the defendant. Unless responsibility is to involve merely paper liability it is necessary to throw the burden of disproving responsibility for repreliensible acts of omission or commission on those who purport to issue statements for the public's reliance. The responsibility imposed is no more or less than that of a trust. It is a responsibility that no honest banker and no honest busmessman should seek to avoid or fear. To impose a lesser responsibility would nullify the purposes of this legislation. To impose a greater responsibility, apart from constitutional doubts, would umiecessarily restram the conscientious administration of honest business with no compensating advantage to the public.

H.R. REP. No. 85, 73d Cong,, 1st Sess. 9-10 (1933). However, two existing SEC safe liarbor rules for replacement cost imformation, 17 C.F.R. $\$ 210.3-17(\mathrm{~g})(1979)$, and oil and gas reserve disclosures under regulation SX, 17 C.F.R. $\$ 210.3-18(\mathrm{k})(6)(\mathrm{v})(1979)$, place the burden on the plamtiff.

148. See Sec. Act Release No. 6084, at 81,940; see, e.g., Marx v. Computer Sciences Corp., 507 F.2d 485 (9th Cir. 1974) (summary judgment for defendants overruled); Green v. Jonhop, Inc., 358 F. Supp. 413 (D. Or. 1973) (management liable for not correcting a misleading forecast). 
general standard of liability. The result of this tactic probably will be that any forecast that fails to meet the Commission's standards will be found misleading. ${ }^{149}$

b. Standards of good faith and reasonable basis. The experimental nature of voluntary disclosure and tle possibility of placing undue reliance on projections led the Commission to determine tliat there must be a good faitl standard in the safe liarbor rule. ${ }^{150}$ Critics attacked earlier proposals that included this requirement because of botll the ambiguity of the term and the lack of any objective standards for determining coinpliance. ${ }^{151}$ Furthermore, the rule requires that forecasts have a reasonable basis. Unlike earlier proposals, lowever, the rule contains no discussion of the factors demonstrating a reasonable basis. ${ }^{152}$

- One major criticism of the rule's approach is tliat a primicipal goal of an effective safe harbor is to create certainty for the disclosing corporation. If the rule itself provided precisely drawn standards backed by examples, certainty would be increased. Even absent precise rules, greater certamty could result if the terms and standards einployed im the rule were judicially well defined. Yet, an analysis of the judicial liability standards developed in the general area of soft information reveals that while certain trends are evident, the courts have not relied on any one standard. ${ }^{153}$ Moreover, few courts liave had an opportunity to examine forecasts in the context of the Commission's present policies. Cases in collateral areas that deal with the good faitl and reasonable basis standards provide no consistent answers.

The court in Beecher v. Able, ${ }^{154}$ for example, used a strict standard for assessing the misleading nature of projections. In this case, purchasers of debentures brought an action against an aerospace inanufacturer based on the company's projection in its prospectus that it would

149. See Gillis, Legal Aspects of Corporate Forecasts, Financial ANAlysts J., Jan.-Feb. 1973, at 72, 76.

150. Sec. Act Release No. 6084 , at $81,940-41$. All of the proposed safe harbor rules have had a good faith requirement. See, e.g., Sec. Act Release No. 5581, supra note 4; REPORT 364. The Report's proposed safe harbor is very similar to the SEC's safe harbor for replacement cost information. Id.

151. See notes 63-64 supra and accompanying text.

152. Several commentators have suggested that a good faith requirement is superfluous, since a projection with a reasonable basis should be treated as having been made in good faith. Sec. Act Release No. 6084, at 81,941 . The SEC response was that numerous security laws contain separate good faith requirements. Id; see, e.g., 15 U.S.C. $\$ \S 78 \mathrm{f}(\mathrm{a}), 78 \mathrm{r}(\mathrm{a}), 78 \mathrm{bb}(\mathrm{e})(1), 80 \mathrm{a}-2(\mathrm{a})(41)(\mathrm{A})$ (1976) (good faith requirements under other provisions of the securities laws).

153. REPORT A-330. See notes 154-75 infra and accoinpanying text.

154. 374 F. Supp. 341 (S.D.N.Y. 1974). 
make nominal income at best. 155 Plaintiffs claimed that the statement was a prediction that the company would break even. As such, the statement was a material misrepresentation, simce the company suffered a disastrous loss of $\$ 52$ million for the year. The company argued that the projection was a warning that if there were any profits the annount would be nominal.

In finding a violation, the court held that "an appreciable nuinber of ordinarily prudent imvestors would have read the statement as a forecast that substantial losses were improbable," 156 and thus, the corporation had not met the "high standard of care" imposed on those who voluntarily make projections. ${ }^{157}$ The court held that projections "must be based on facts from which a reasonably prudent investor would conclude that it was highly probable that the forecast would be realized." 158 Moreover, material underlying assuinptions must be disclosed to prevent the forecast from being misleading. ${ }^{159}$

The Beecher court's "highly probable" test has not been followed by other courts. Instead, courts have focused on three general requirements in determining hability: (1) good faith; (2) reasonable basis; and (3) appropriate qualification and explanation of the projections. Several cases provide examples of how courts have struggled to define these concepts. The earliest projection cases established the good faith requirement. As Judge Learned Hand said im one such case, "[I]t has been the law ever simce 1896, that to promise what one does not mean to perform, or to declare an opimion as to future events which one does not hold, is a fraud." 160 Other courts have contmued this basic require-

155. The action was brought under section 11 of the Securities Act of 1933,15 U.S.C. $\$ 77 \mathrm{k}(\mathrm{a})$ (1976), which provides a cause of action for a person who has purchased a security pursuant to a registration statement and prospectus that either contained an untrue statement of a material fact or failed to state a material fact.

156. 374 F. Supp. at 347.

157. Id. at $347-48$.

158. Id. at 348 (footnote omitted).

159. Id. The court did, however, explain that "[a]ll projections will be based on numerous assumptions, some of which are so reasonable and so likely to be borne out by the facts that they may be left unstated." Id. at 348 n.6. But cf. Dolgow v. Anderson, 53 F.R.D. 664, 668 (E.D.N.Y. 1971) (disclosure of assumptions not required), aff'd per curiam, 464 F.2d 437 (2d Cir. 1972). In addition, the Beecher court considered the company's poor forecasting record and its reliance on unreasonable, as well as undisclosed, assumptions as evidence that the projection was misleading. The court stated that the company should have disclosed the fact that its previous forecasts had failed, so that investors would know that the company's forecasting techniques were faulty or that adverse conditions affecting the company made it difficult to make reliable forecasts. The court also maintaimed that the company should have disclosed its assuinption that substantial improvements would be made in the Aircraft Division in order to avoid substantial losses. $374 \mathrm{~F}$. Supp. at 354.

160. United States v. Grayson, 166 F.2d 863, 866 (2d Cir. 1948) (footnote omitted). This case involved predictions of enormous oil profits. The argument was made that opinions, promises, or 
ment of a good faith belief in the projection at the time it is made. ${ }^{161}$ In addition, most courts have required that the underlying data and nethod of preparation provide a reasonable basis for the projection.

The leading case of Dolgow v. Anderson ${ }^{162}$ illustrates the application of the reasonable basis requirement. Monsanto Corporation and its officers were sued under rule $10 \mathrm{~b}-5$ for predictimg an imcrease im earnings when there was in fact a ten-percent decline in net income. The court held that the projection was neither misleading nor fraudulent, however, because of Monsanto's thorough preparation and careful documentation of the projection. ${ }^{163}$ The Dolgow court considered numerous factors in finding that the projection was reasonably based. Monsanto had a program for advising the public of the results of past operations and of future prospects; ${ }^{164}$ the company's imternal documents were appropriately prepared and extensively reviewed by all levels of management; 165 internal data supported the projections when they were made; and the projections were constantly updated and revised. ${ }^{166}$ The court concluded that the projections were made honestly, were reasonable, and were the best estimates available to manageinent. ${ }^{167}$ In addition, it was possible to attribute the decline in income to several unanticipated economic events that affected the profits of the industry as a whole. ${ }^{168}$

The Court of Appeals for the Ninth Circuit, in Marx v. Computer Sciences Corp. ${ }^{169}$ held that a forecast of earnings is misleading if either

representations about the future would not support a charge of fraud. The court held just the opposite.

161. See, e.g., Sunstrand Corp. v. Sun Chemical Corp., 553 F.2d 1033, 1040 (7th Cir.), cert. denied, 434 U.S. 875 (1977); Marx v. Computer Sciences Corp., 507 F.2d 485, 490 (9th Cir. 1974); Schuller v. Slick Corp., [1974-75 Transfer Binder] FED. SEC. L. REP. (CCH) \ 95,065 (S.D.N.Y. 1975).

162. 53 F.R.D. 664 (E.D.N.Y. 1971), affd per curiam, 464 F.2d 437 (2d Cir. 1972).

163. 53 F.R.D. at 686 .

164. Id. at 674 .

165. Id. at 676 .

166. Id. at $676-77$.

167. Id. at 676,679 .

168. Id. at 673. Several commentators have read Dolgow very broadly. For example, one commentator concluded that the Dolgow court provides a safe harbor for inaccurate projections that were made in "good faith and with reasonable prudence." Schneider 304. Another suggests that the court "clearly applied a negligence standard, based on the 'reasonable busimessman,' and seemingly was very tolerant of missed forecasts caused by external events that werc unforeseeable." Wise, supra note 29, at 515-16; $c f$. REA Express, Inc. v. Interway Corp., 410 F. Supp. 192, 196-97 (S.D.N.Y. 1976) (company publicized a prediction based on data made obsolete by a cliange in business conditions; court lield "[a]bsent a reasonable method of preparation or a valid basis, reckless and unfounded statements as to future earmings . . . are sufficiently misleading to be actionable under Rule 10b-5").

169. 507 F.2d 485 (9th Cir. 1974). 
good faith or a reasonable basis is lacking. ${ }^{170}$ As discussed earlier, ${ }^{171}$ the company had inaccurately projected that certain costs would be amortized and profits would be substantial. In formulating a liability standard, the court assumed that the prediction was a material fact and proceeded to determine whether it was untruc:

Of course in hindsight it turned out to be wrong. But at least in the case of a prediction as to the future, that in itself does not make the statement untrue when made. However, the forecast may be regarded as a representation that on January 23, 1970, CSC's inforined and reasonable belief was that at the end of the coming period, earnings would be approximately $\$ 1.00$. That is what a reasonable investor would take the statement to mean, and we believe it would be "untrue" when made if CSC did not then believe earnings would be in that amount or knew that there was reason to believe they would not be. In addition, because such a statement imphes a reasonable method of preparation and a valid basis, we believe also that it would be "untrue" absent such preparation or basis. ${ }^{172}$

The Court of Appeals for the Eighth Circuit, in Polin v. Conductron Corp. ${ }^{173}$ suggested a slight variation in the standard employed in Marx. The court lield that a forecast by an electronics corporation did not constitute a misrepresentation even though the forecast was inade without a reasonable basis. According to the court, when reliable information is not available, it is sufficient for the firm to explain the uncertaimties and inadequacies of the forecast because such explanation and qualification coupled with good faith will prevent a misrepresentation. ${ }^{174}$

These cases demonstrate that the courts have not developed uniform standards for determining hability for forecasts that prove inaccurate. At inost, an analysis of the cases shows that the potential for hability is greater if a forecast is not made in good faith and with a

170. Id. at 490 .

171. See text accompanying notes 100-01 supra.

172. 507 F.2d at 489-90. See also Scluller v. Slick Corp., [1974-75 Transfer Binder] FED. SEC.L. REP. (CCH) I 95,065, at 97,739 (S.D.N.Y. 1975).

173. 552 F.2d 797 (8th Cir.), cert. denied, 434 U.S. 857 (1977).

174. 552 F.2d at 806-08. See also SEC v. Geotek, 426 F. Supp. 715 (N.D. Cal. 1976). In Goetek, an estimate in a prospectus was worded as follows: "while it is not possible to predict accurately at this time the allocation of net proceeds, it is estimated that approximately . . .5\% [of such proceeds will be utilized] for general and administrative costs." Id. at 753. The court held that there was insufficient evidence to show that the prediction was other than a good faith estimate of costs based upon certain new cost-cutting programs and an anticipated mcrease in the sale of partnership interests in certain programs. Id. Similarly, Judge Weinstein, in Feit v. Leasco Data Processing Equip. Corp., 332 F. Supp. 544 (E.D.N.Y. 1971), suggested that an unreliable basis for a forecast would not be a ground for liability if it were accompanied by an appropriate qualifying statement. The court provided an example of an acceptable quahification. Id. at 560 . See notes 102-06 supra and accompanying text. 
reasonable basis; but there is no consensus about the meaning of these concepts. Furthermore, a forecast that meets the good faith and reasonable basis standards may still result in liability if the projection is not appropriately explained througli the disclosure of underlying assumptions or appropriately qualified by cautionary statements about its reliability. ${ }^{175}$ Finally, a projection that is made in good faith and with a reasonable basis, but that omits material facts may also create liability.

While these statements provide some guidance, their generality reflects the degree of uncertainty that exists in this area. Rule 175 merely formalized this uncertainty by usmg the good faith and reasonable basis standards witliout elaborating how these requirements can be fulfilled. It has been suggested, for example, that the good faith standard under the rule 175 safe harbor incorporates the courts' requirement of appropriate qualification and explanation. ${ }^{176}$ Thus, a plamtiff alleging that management issued a misleading forecast would have to prove lack of good faith, reasonable basis, and adequate qualification and explanation. ${ }^{177}$ An issuer might assuine, however, that good faith simply means an honest belief in the truth of the forecast-the usual defimition of the term under the securities laws. The rule does not indicate whicls is the proper interpretation. Similarly, the reasonable basis requirement is not defined or explained. It is unclear whether the term means reasonable preparation, such as review by appropriate levels of management and proper format, or reasonable underlying data, which

175. The appropriate qualification and explanation requirement has not been as clearly articulated as the other two requirements, yet it appears to be a major factor in several of the cases. See, e.g., Marx v. Computer Sciences Corp., 507 F.2d 485, $491-92$ (9th Cir. 1974). Although the SEC did not exphicitly include this requirement in the safe harbor rule, the 1976 proposed guides required that projections be presented in an appropriate format, and accompanied by information adequate for investors to make their own judgments. See Sec. Act Release No. 5699. See also N.Y. Stock Exchange Company Manual A-22 (1977) (adopts appropriate qualification requirement); Fiflis 125, 145 (managers will be safe from liabihty for statements that are made in good faith with a reasonable basis, and that are adequately quahified). See notes 167-74 supra and accoinpanying text.

176. See J. Cox 292; Fiflis 125-26. The American Law Institute Federal Securities Code incorporates the definitions of fact and misrepresentation to produce a similar result:

Sec. 256. [Fact.] "Fact" includes (a) a promise, prediction, estimate, projection, or forecast, or (b) a statement of imtention, motive, opimion, or law. See also section 297(b).

Sec. 297. [Misrepresentation.] (a) [General.] "Misrepresentation" means (1) an untrue statement of a material fact, or (2) an omission to state a material fact necessary to prevent the statements made from being misleading in the light of the circumstances under which they are made.

(b) [Estimates, etc.] A statement of a fact within the meaning of section 256(a) is not a misrepresentation if it (1) is made in good faith, (2) has a reasonable basis when it is made, and (3) complies with any applicable rule so far as underlying assumptions or other conditions are concerned.

ali, federal Securities Code, Proposed Official Draft (1978).

177. Fiflis 125-26. 
is not outdated or unreliable, or both.

The solution is to set clearer standards, so that those who want to disclose may do so witl some certainty that liability will not result. The task of clarification could be left to the courts; however, the problem of unpredictability would most likely remain, thus discouraging companies that might otherwise disclose projections. A better approacli would be for the Commission to provide the guidance for both companies and courts by enunciatimg standards that are nore precise than catchwords sucl as "reasonable basis" and "good faith," and yet are not as restrictive as the quantitative tests contained in the origmal safe harbor proposal. ${ }^{178}$ One commentator has suggested that the Securities and Exchange Commission has reframed from providing clear standards for disclosure because it fears that specific benchmarks will facilitate fraud and will be expected to provide for every contimgency. 179

A comprehensive approach, lowever, is not essential. Rather, the Commission should be encouraged to establish guidelines only in those areas in which satisfactory guidelines can be drawn sucl as by defining reasonable basis and good faith. Clear standards under the safe liabor rule would be of substantial benefit to nranagements and their attorneys who must determine whether and in what form they will disclose their forecasts. ${ }^{180}$

\section{CONCLUSION}

The purpose of the securities laws is to ensure the full disclosure of material information so tliat imvestors can make informed decisions. The Commission lias taken a step in the right direction by providing a safe harbor for forecasts made in good faitl and witl a reasonable basis. There are several amendments to tlie rule, lowever, that should be implemented ni $_{1}$ order for the safe harbor fully to achieve its purpose. The most radical, and perliaps the most effective, antendment would be to require disclosure of forecasts. A mandatory system would assure investors access to valuable investment information and would relieve management of the burden of deciding what it sliould disclose. At a minimum, the Commission slould require disclosure of assumptions

178. See notes 114-21 supra and accompanying text.

179. Blackstone, $A$ Roadmap for Disclosure vs. A Blueprint for Fraud, 26 U.C.L.A. L. REv. 74, 79 (1978).

180. Id. 81 (suggesting that tests for materiality would be helpful in determining what information should be disclosed). 
and corrections. In addition, the Commission should formulate clearer standards to aid the conscientious in avoiding potential liabilities and to direct the courts in establishing standards.

Kimberly Till 